\title{
A novel DAG-dependent mechanism links PKCa and Cyclin B1 regulating cell cycle progression
}

\author{
Alessandro Poli ${ }^{1}$, Giulia Ramazzotti ${ }^{1}$, Alessandro Matteucci ${ }^{2}$, Lucia Manzoli ${ }^{1}$, \\ Annalisa Lonetti ${ }^{1}$, Pann-Ghill Suh ${ }^{3}$, James A. McCubrey ${ }^{4}$, Lucio Cocco ${ }^{1}$ \\ ${ }^{1}$ Cell Signaling Laboratory, Department of Biomedical Sciences, University of Bologna, Bologna, BO 40126, Italy \\ ${ }^{2}$ CNR-National Research Council of Italy, Institute of Molecular Genetics, Bologna, BO 40126, Italy \\ ${ }^{3}$ School of Nano-Biotechnology and Chemical Engineering, Ulsan National Institute of Science and Technology, Ulsan, \\ Republic of Korea \\ ${ }^{4}$ Department of Microbiology and Immunology, Brody School of Medicine, East Carolina University, Greenville, NC, USA
}

Correspondence to:

Lucio Cocco, e-mail: lucio.cocco@unibo.it

Keywords: PKC, Cyclin, Cell Cycle, PLC, DAG, nuclei

Received: September 02, $2014 \quad$ Accepted: October 06, $2014 \quad$ Published: October 24, 2014

\section{ABSTRACT}

Through the years, different studies showed the involvement of Protein Kinase C (PKC) in cell cycle control, in particular during G1/S transition. Little is known about their role at G2/M checkpoint. In this study, using $\mathrm{K562}$ human erythroleukemia cell line, we found a novel and specific mechanism through which the conventional isoform PKCa positively affects Cyclin B1 modulating G2/M progression of cell cycle. Since the kinase activity of this PKC isoform was not necessary in this process, we demonstrated that $\mathrm{PKC}_{\mathrm{a}}$, physically interacting with Cyclin B1, avoided its degradation and stimulated its nuclear import at mitosis. Moreover, the process resulted to be strictly connected with the increase in nuclear diacylglycerol levels (DAG) at G2/M checkpoint, due to the activity of nuclear Phospholipase C $\beta 1$ (PLC $\beta 1$ ), the only PLC isoform mainly localized in the nucleus of $\mathrm{K562}$ cells. Taken together, our findings indicated a novel DAG dependent mechanism able to regulate the G2/M progression of the cell cycle.

\section{INTRODUCTION}

Protein kinase $\mathrm{C}$ (PKC) is a family of serine/ threonine kinases involved in different biological functions [1-3]. Ten PKCs are present in mammalian cells and are divided in three classes based on their structure domains and activation [1-3]. Indeed, activation of conventional PKCs (PKC $\alpha, \beta \mathrm{I}, \beta \mathrm{II}$ and $\gamma$ ) requires the lipid second messengers diacylglycerol (DAG) and $\mathrm{Ca}^{2+}$, while novel isozymes (PKC $\delta, \varepsilon, \theta$ and $\eta$ ) need only DAG. On the contrary, the atypical class (PKC $\zeta$ and $\lambda / \mathrm{r}$ ) is not sensible to any of them, and its activation is due to protein-protein interactions [1-3]. Our knowledge about the involvement of these enzymes in cell cycle regulation is very wide at the moment and, through the years, it became clear that these effects are linked to the different contexts where they take place [2-4]. As a matter of fact, many studies reported roles for PKCs in cell cycle both as anti-proliferative and growth-stimulatory enzymes [2-5]. Modulation of cell proliferation by PKCs is characterized by high complexity, effecting different molecules involved in the control of the cell cycle including cyclins, cyclindependent kinases (Cdk), Cip/Kip inhibitors and Lamins [2, 4-8]. However, several evidences indicated Cip/Kip inhibitors and D-type cyclins as the most frequent targets for PKCs. Indeed, many studies described the involvement of PKCs in G1/S transition regulating Cyclin D1, p21/ Cip1 or p27/Kip1 expressions in different cell lines $[2,4,8-11]$. Recently, we found that PKC $\alpha$ was necessary in PLC $\beta 1$ mediated regulation of Cyclin D3 and cell proliferation in human erythroleukemia cells $[12,13]$. On the other hand, little is known about the role of PKCs at G2/M phase [2, 4]. Different studies showed their peculiar ability to partially translocate 
into the nuclei influencing this phase of the cell cycle. In particular, nuclear import of PKCs was correlated to the increase of nuclear diacylglycerol (DAG) before mitosis [6] [14] [15-18]. These findings were supported by Fiume et. al, who demonstrated that $\mathrm{PKC} \alpha$, once in the nuclei, could phosphorylate Lamin B1 stimulating lamin dissociation and G2/M progression [19]. In this study, investigating other possible roles for PKCs at G2/M phase, we found that Cyclin B1 can positively be modulated by $\mathrm{PKC} \alpha$. As widely described in literature, the entry of eukaryotic cells into mitosis is due to the activation of cyclin dependent kinase 1 (Cdk1), which complexes with its regulatory subunit Cyclin B1 to form the mitosis-promoting factor (MPF) [21-28]. MPF remains inactive until $\mathrm{Cdk} 1$ is phosphorylated at Thr161 by Cdk activating kinase (CAK) and de-phosphorylated by Cdc25c at Thr14/Thr15 [20-28]. In addition, Cyclin B1 is phosphorylated by Cdk1 and Polo-like kinase 1 (PLK1) in its cytoplasmic retention signal (CRS) domain, which regulates its nuclear translocation at late prophase [21-28]. This nuclear accumulation has been highly studied and described, but remains not completely understood for the lack of a canonical nuclear localization signal (NLS) in Cyclin B1 structure, usually necessary for nuclear import through the karyopherins system [21-29]. However, once in the nuclei, Cyclin B1/Cdk1 complex phosphorylates a wide number of substrates driving the cells into mitosis [20-28]. Finally, at the end of the mitotic process, Cyclin B1 starts to be degraded by the APC/C complex and Cdk1 undergoes inactivation leading cells to mitotic exit and cytokinesis [21-32]. Here, we describe, for the first time, a DAG dependent mechanism linking PKC $\alpha$ to Cyclin B1 at G2/M checkpoint. Indeed, investigating whether $\mathrm{PKCs}$ could affect $\mathrm{G} 2 / \mathrm{M}$ progression in K562 cell line, we found that Cyclin B1 was positively modulated by PKC $\alpha$. This event was independent of the kinase activity of the enzyme. Moreover, PKC $\alpha$ resulted to physically interact with Cyclin B1 during cell cycle progression, avoiding its degradation and promoting its nuclear accumulation. Finally, we observed how DAG accumulation in nucleus, due to the activity of nuclear PLC $\beta 1$, could modulate Cyclin B1 and PKC $\alpha$ nuclear translocation at $\mathrm{G} 2 / \mathrm{M}$ checkpoint.

\section{RESULTS}

\section{PKCs affect Cyclin B1 levels in K562 cells}

In order to find whether PKCs could target Cyclin B1 expression during cell cycle of K562 cell line, we treated cells with three different PKC inhibitors at a final concentration of $1 \mu \mathrm{M}$ : Go6983, Go6976 and 3-(1-(3-imidazol-1-ylpropyl)-1H-indol-3-yl)-4-anilino1H-pyrrole-2,5-dione anilinomonoindolylmaleimide (from here simply PKC inhibitor) $[1,2,19][33,34]$.
Next, we synchronized the cells at G2/M checkpoint using Nocodazole $(20 \mathrm{ng} / \mathrm{ml})$ for 16 hours to avoid any cell cycledependent modulation of Cyclin B1 expression. Notably, immunoblot analyses showed an important decrease of Cyclin B1 levels only in cells treated with PKC inhibitor. The effect appeared to be concomitant with the high reduction of PKC $\alpha$ and $\mathrm{PKC} \beta \mathrm{II}$, the only two conventional $\mathrm{PKC}$ isoforms expressed in our model $[12,35,36]$. This down-modulation of the level of PKCs was not linked to their reduced gene expression (Supplementary Figure 1) but, probably, to side effects on other enzymes involved in PKC regulation. On the contrary, using Go6976 and Go6983, which inhibited only PKC activity [33], we did not observe any appreciable change in Cyclin B1 expression. In addition, we stimulated PKC signalling using Phorbol-12-Myristate-13-Acetate (PMA) at a final concentration of 50nM for 16 hours. Interestingly, synchronized K562 cells at G2/M checkpoint showed an important decrease of Cyclin B1 parallel to PKC $\alpha$ and PKC $\beta$ II degradation. PKCs degradation was probably due to their hyper-activation by PMA [35-37], Cyclin B1 down-modulation seemed to be related to the decrease of PKCs in the cells as well as during treatments with PKC inhibitor (Figure 1A).

\section{$\mathrm{PKC} \alpha$ is the conventional isoform that modulates Cyclin B1 affecting cell cycle progression}

In order to understand which of the two conventional PKC isoforms was responsible of the phenomenon described above, we transiently silenced both of them using RNA interference techniques (PKC $\alpha \mathrm{KD} / \mathrm{PKC} \beta \mathrm{II} \mathrm{KD})$. More than one siRNA was used for the experiments in order to exclude any offtarget effects and no changes in the results were found (see materials and methods). A Scrambled siRNA was used as control (Scrambled). 24 hours after transfection, using Nocodazole, we synchronized the cells at G2/M checkpoint. Here, we observed a strong down-regulation of Cyclin B1 only in cells characterized by PKC $\alpha$ knockdown. PKC $\beta I I$ did not affect it at all (Figure 1B). Next, to confirm that this modulation was due to a specific effect of PKC $\alpha$ on Cyclin B1, we screened other proteins related to $\mathrm{G} 2 / \mathrm{M}$ progression. None of these molecules was affected (Supplementary Figure 2). In addition, we also investigated if $\mathrm{PKC} \alpha$ could be responsible for Cyclin B1 phosphorylations, including Ser133 and Ser147, but it was not (Supplementary Figure 2). However, we found that this specific modulation of Cyclin B1 could affect cell cycle progression. In order to investigate these effects, we silenced PKC $\alpha$ and we synchronized the cells at G2/M. Then, we removed Nocodazole, we washed the cells in PBS and we seeded them again in complete RPMI 10\% FBS. 24 hours later, cell cycle analyses indicated that $\mathrm{PKC} \alpha$ silencing drove the cells to 
a)
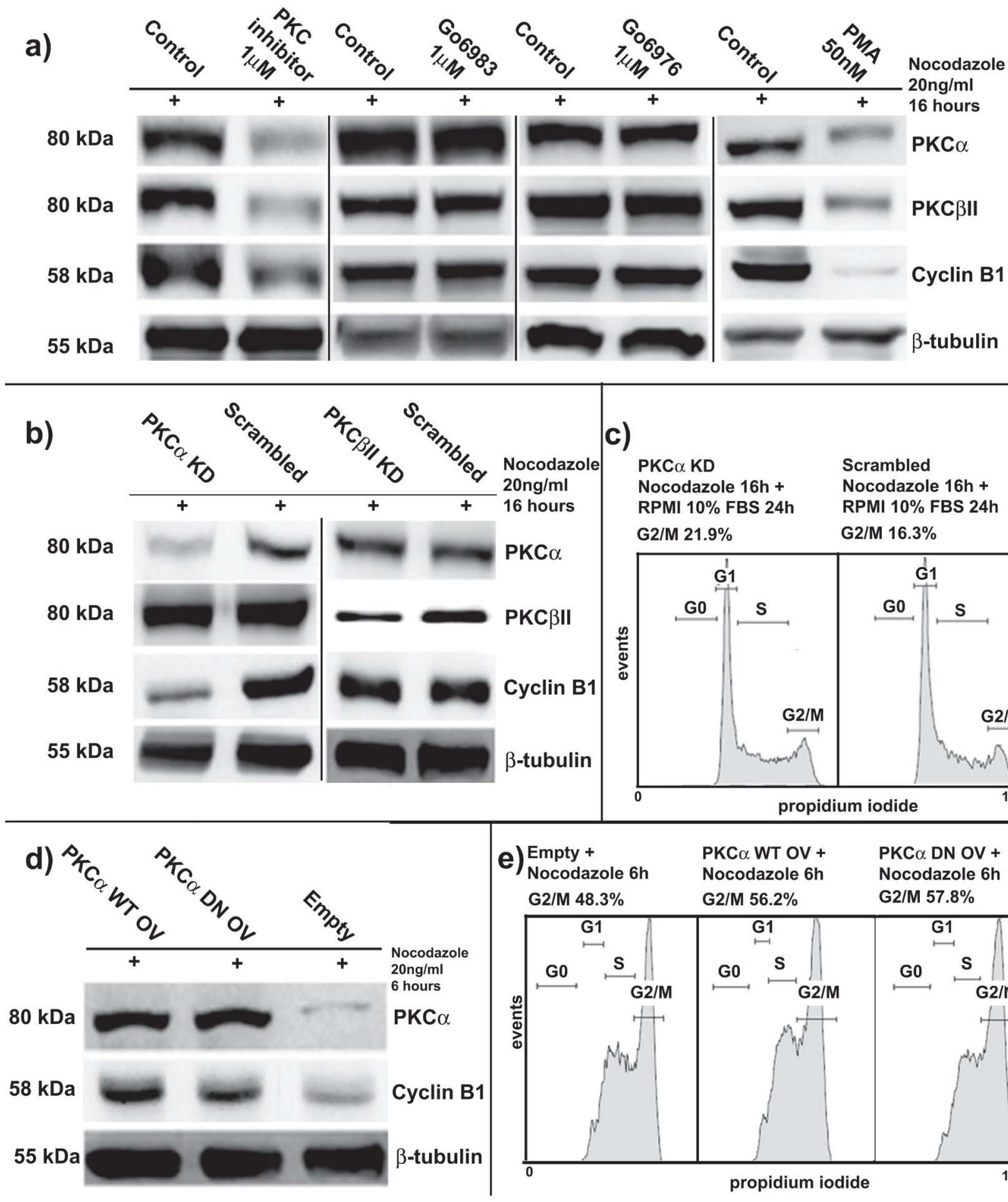

c) \begin{tabular}{l|l} 
Nocodazole & PKC $\alpha$ KD \\
$20 \mathrm{ng} / \mathrm{ml}$ & Nocodazole 16h + \\
16 hours & RPMI 10\% FBS 24h
\end{tabular}

Scrambled

Nocodazole $16 \mathrm{~h}+$ G2/M 21.9\%

RPMI $10 \%$ FBS $24 \mathrm{~h}$

PKC $\alpha$

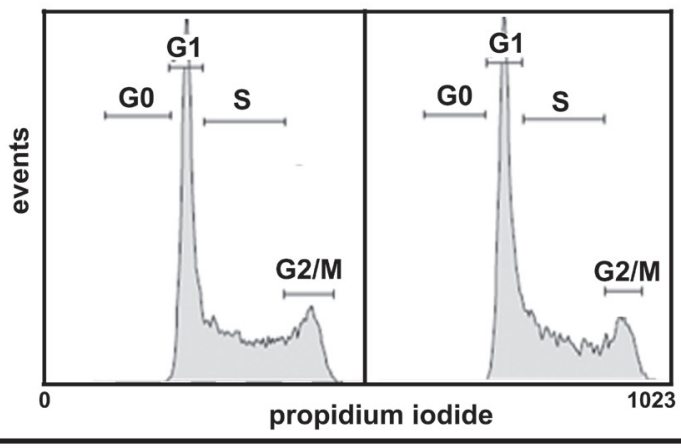

$\beta$-tubulin

CKC $\beta$ II

(2)
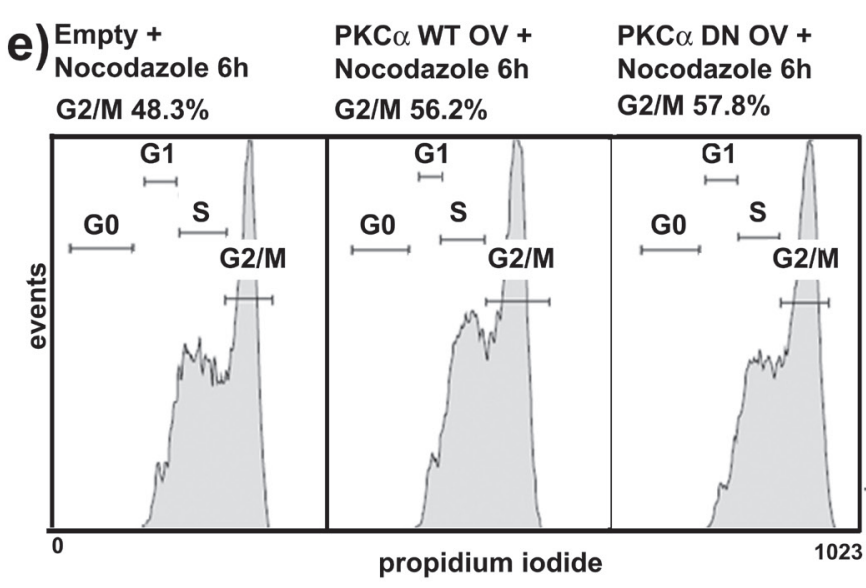

Figure 1: Protein kinase $\mathbf{C} \boldsymbol{\alpha}(\mathbf{P K C} \alpha)$ involvement in Cyclin B1 regulation. (a) K562 cells were treated with three different PKC inhibitors (PKC inhibitor, Go6983, Go6976) and with phorbol-12-myristate-13-acetate (PMA). Cells were synchronized at G2/M by Nocodazole. PKCs decrease led to a severe downregulation of Cyclin B1 expression if compared to the controls (Control). (b) PKC $\alpha$ and PKC $\beta$ II were silenced for 48 hours (PKC $\alpha$ KD/PKC $\beta I I$ KD). Cells were synchronized at G2/M using Nocodazole. A scrambled siRNA was used as control (Scrambled). Only PKC $\alpha$ silencing drove to Cyclin B1 downmodulation. The silencing was performed using different siRNAs to avoid any possible off-target effects. (c) Cells, blocked at G2/M, were seeded again in complete RPMI 10\% FBS. 24 hours later, cell cycle analysis was performed indicating an accumulation at G2/M in PKC $\alpha$ knock-down conditions. (d) PKC $\alpha$ was overexpressed using a Wild Type (PKC $\alpha$ OV WT) or a Dominant Negative (PKC $\alpha$ OV DN) vector. Cells were stimulated to accumulate at G2/M using Nocodazole for 6 hours. Empty vector was used as control (Empty). Overexpression of PKC $\alpha$ WT and DN lead to an upmodulation of Cyclin B1. (e) Cells were treated using Nocodazole as in d) and cell cycle analysis was performed indicating an higher accumulation at $\mathrm{G} 2 / \mathrm{M}$ of cells overexpressing PKC $\alpha$. 
a higher G2/M accumulation compared to the controls. This could be related to the lack of Cyclin B1 caused by PKC $\alpha$ silencing. Indeed, accordingly to literature, a high decrease of Cyclin B1 could interfere with the transition through the G2/M phase of cell cycle [38]. Moreover, the same experiments were performed using PKC inhibitor, whose effects on cell cycle were stronger but very similar to $\mathrm{PKC} \alpha$ silencing (Supplementary Figure 3). Finally, we analyzed proliferation of K562 cell line. We silenced PKC $\alpha$ and, 24 hours later, we synchronized the cells using Nocodazole. Then we removed the G2/M block seeding the transfected cells in complete RPMI 10\% FBS at a cell density of $10 \times 10^{5} / \mathrm{ml}$. Experiments of cell counting, performed for 72 hours, showed that PKC $\alpha$ silencing did slow-down cell proliferation of K562 cells compared to the controls. The same effects were noticed using PKC inhibitor (Supplementary Figure 4).

\section{PKC $\alpha$ activity was not necessary for Cyclin B1 modulation}

Since PKC $\alpha$ positively modulated Cyclin B1 levels in $\mathrm{K} 562$ cells, we decided to investigate if its kinase activity was necessary to this process. Then, we transiently overexpressed PKC $\alpha$ using two different vectors, a Wild Type vector (PKC $\alpha$ OV WT) and a Dominant Negative mutant (PKC $\alpha$ OV DN). Empty vector (Empty) was used as control. 24 hours after the transfections, we added Nocodazole for 6 hours to drive the cells to G2/M. This partial synchronization was performed to stimulate Cyclin B1 accumulation and study if PKC $\alpha$ overexpression could promote this process. Notably, in cells characterized by $\mathrm{PKC} \alpha \mathrm{WT}$ or DN overexpression, we found the same increase of Cyclin B1 compared to the controls (Figure 1D). As a further proof that the kinase activity of PKC $\alpha$ was not necessary in this process, we analyzed cell cycle of these samples. Overexpression of the two PKC vectors, WT and DN, led the cells to a quicker accumulation at $\mathrm{G} 2 / \mathrm{M}$ than the controls. In addition, cell counting analyses demonstrated that up-modulation of PKC $\alpha$ was able to increase K562 cell proliferation (Supplementary Figure 4). Taken together, these data suggested that the kinase activity of PKC $\alpha$ was not necessary in Cyclin B1 modulation.

\section{Lack of PKCa leads to a faster degradation of Cyclin B1 in $\mathrm{K562}$ cell line}

In order to deeply understand how PKC $\alpha$ could affect Cyclin B1, we decided to investigate at which level this modulation took place. We silenced or overexpressed PKC $\alpha$ and we synchronized K562 cells as previously described. We performed gene expression analyses of Cyclin B1, but we did not find any changes in its expression levels (Figure 2A). These evidences suggested the existence of a post-transcriptional effect on Cyclin B1 by PKCa. Then, we focused our studies on Cyclin B1 degradation, implying a possible role for PKC $\alpha$ as a scaffold molecule. As already reported [30, 31], Cyclin B1 undergoes degradation at the end of mitosis. Thus, we used a proteasome inhibitor, MG-132, to block protein degradation after $\mathrm{G} 2 / \mathrm{M}$ release. Our findings showed that treating K562 cells with MG-132 up to two hours, at a final concentration of $15 \mu \mathrm{M}$, blocked Cyclin B1 degradation driving to its accumulation in the cells (Supplementary Figure 5). Then, we silenced PKC $\alpha$ and, 48 hours later, we divided transfected cells in two aliquots; one was treated with MG-132 for two hours, one was seeded in complete RPMI 1640 10\% FBS and used as control. Notably, MG-132 treated cells showed a peculiar and significant increase of Cyclin B1 levels compared to the control. PKC $\alpha$ expression remained silenced in both samples (Figure 2B). These evidences indicated that the presence of PKC $\alpha$ inhibited the degradation of Cyclin B1 in K562 cells. In addition, as a positive control, we decided to investigate the Cip inhibitor p21 [39], already described to highly accumulate during Cyclin B1 degradation [40]. Interestingly, in cells transfected to silence PKC $\alpha$, the decrease of Cyclin B1 was concomitant with an important up-modulation of p21/Cip1 levels (Figure 2C). Taken together, these data supported our theory, showing that lack of PKC $\alpha$ drove to a faster degradation of Cyclin B1 in K562 cells.

\section{Cyclin B1 and PKCa interact during cell cycle progression}

In this series of experiments, we focused on the expression and localization of Cyclin $\mathrm{B} 1$ and $\mathrm{PKC} \alpha$ during cell cycle progression. Then, we treated our cells to promote their accumulation in the desired cell cycle phases. In particular, we starved K562 cells, using HBSS for 16 hours, to obtain a G0-G1 synchronization (G0-G1). G1/S phase was referred to proliferating cells in normal and complete RPMI 1640 10\% FBS (G1/S). Finally, using Nocodazole, we obtained a G2/M block (G2/M) (Figure 3A). Firstly, immunoblot analyses showed a progressive increase of Cyclin B1 and PKC $\alpha$ expression through the cell cycle peaking at G2/M. Next, separating nuclei of $\mathrm{K} 562$ cells from the cytoplasms, we investigated their localization along the different phases. Notably, PKC $\alpha$ accumulated in the nucleus especially in $\mathrm{G} 2 / \mathrm{M}$ cells as well as Cyclin B1 (Figure 3B). This similar co-localization was also confirmed by immunocytochemistry analyses (Figure 3C). Next, we decided to see if these two proteins could interact during cell cycle. After seeing that our immunoprecipitation experiments worked properly (Figure $3 \mathrm{D}$ ), we synchronized the cells at G2/M checkpoint and we performed co-immunoprecipitation analyses to seek the possible formation of complexes between the two enzymes. Interestingly, our findings showed that $\mathrm{PKC} \alpha$ and Cyclin B1 could interact (Figure 3D). As in the 

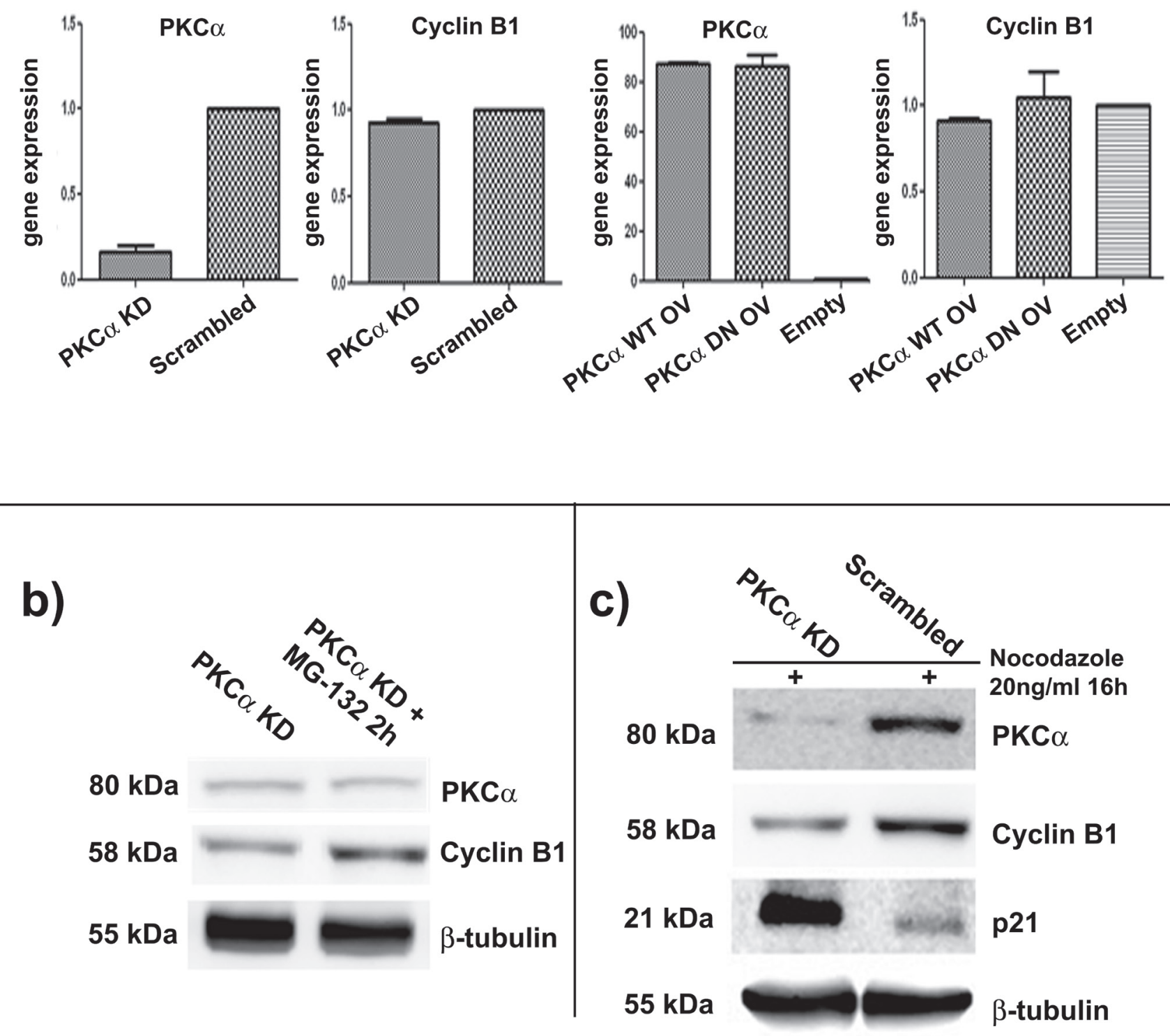

Figure 2: Lack of PKCa drives to a faster degradation of Cyclin B1. (a) Gene expression analyses of Cyclin B1 in conditions of silencing or overexpression of PKC $\alpha$. Cells were synchronized at G2/M. Cyclin B1 expression is not affected by modulation of PKC $\alpha$. (b) $\mathrm{PKC} \alpha$ was silenced and, 48 hours later, transfected cells were divided in two aliquots: one used as control (PKC $\alpha$ KD) and one treated with MG-132 for 2 hours (PKC $\alpha$ KD + MG-132 2h) The treatment blocked Cyclin B1 degradation and led to its accumulation in the cells. No changes in PKC $\alpha$ levels were detected. These evidences suggested that down-modulation of Cyclin B1 due to lack of PKC $\alpha$ was ceased inhibiting the proteasome machinery. (c) PKC $\alpha$ was silenced and cells synchronized at G2/M. Silencing of PKC $\alpha$ (PKC $\alpha$ KD) leads to an accumulation of p21 compared to the control (Scrambled). This effect is opposite to Cyclin B1 decrease. p21 was used as a marker of degradation for Cyclin B1.

negative control (IgG) of $\mathrm{PKC} \alpha$ immunoprecipitation appeared a partial non-specific band, probably due to cross-reaction between the antibody, we repeated the experiments more than 4 times. Moreover, interaction between the two proteins was detected also in G1/S cycling cells, which confirmed the capacity of PKCa and Cyclin B1 to complex during cell cycle progression (Supplementary Figure 6). Next, in order to further investigate the existence of this complex, we again immunoprecipitated PKC $\alpha$ and we found it was able to interact with $\mathrm{cdk} 1 / \mathrm{cdc} 2$, the kinase that forms the MPF associating with Cyclin B1 [20-25], [26], [27, 28]. As positive control of the experiment, we immunoprecipitated Cyclin B1 finding it perfectly complexed with cdk1/ cdc2 (Figure 3E). Finally, we repeated these experiments separating nuclei from cytoplasms of cells synchronized at 


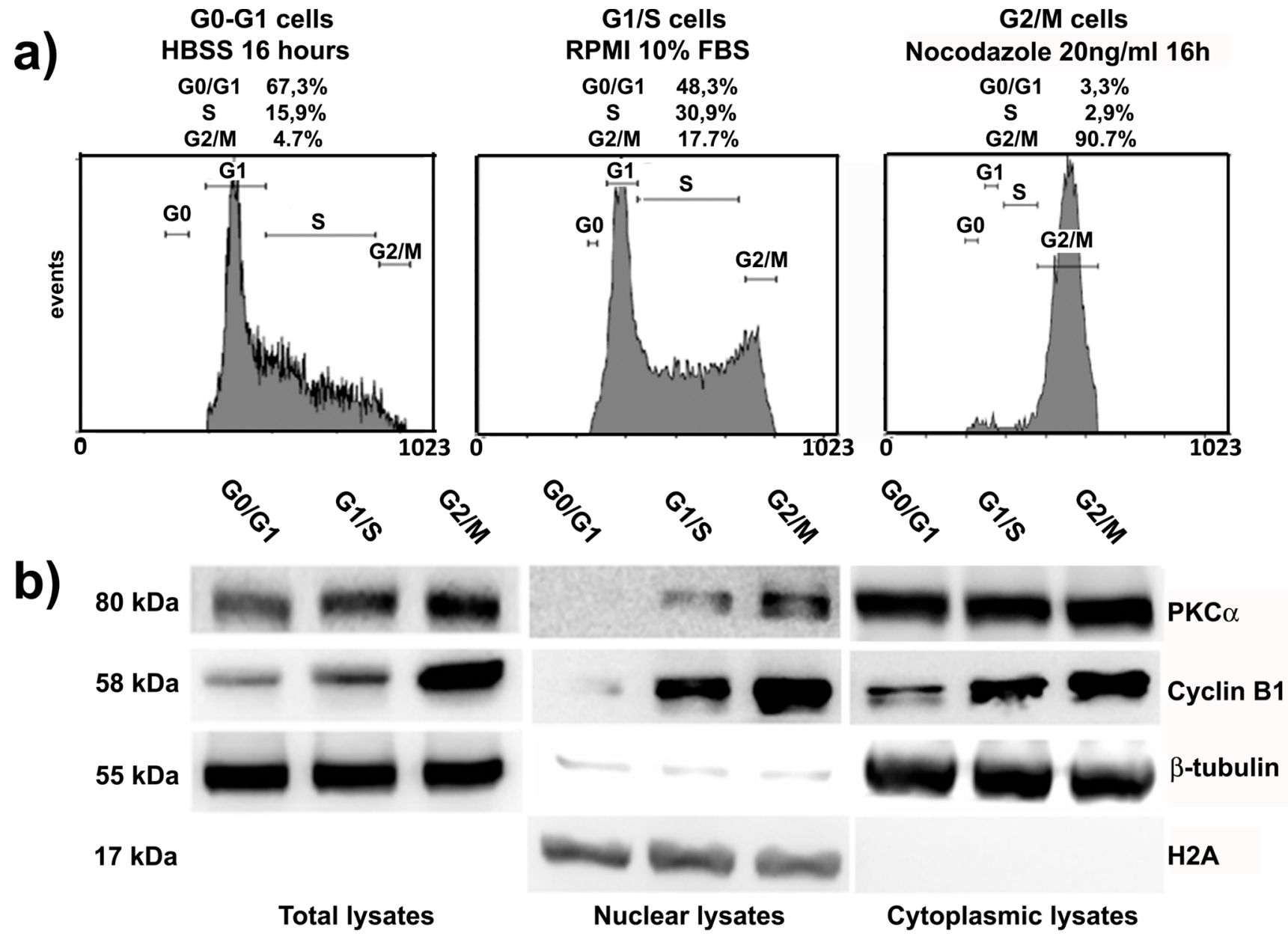

c)

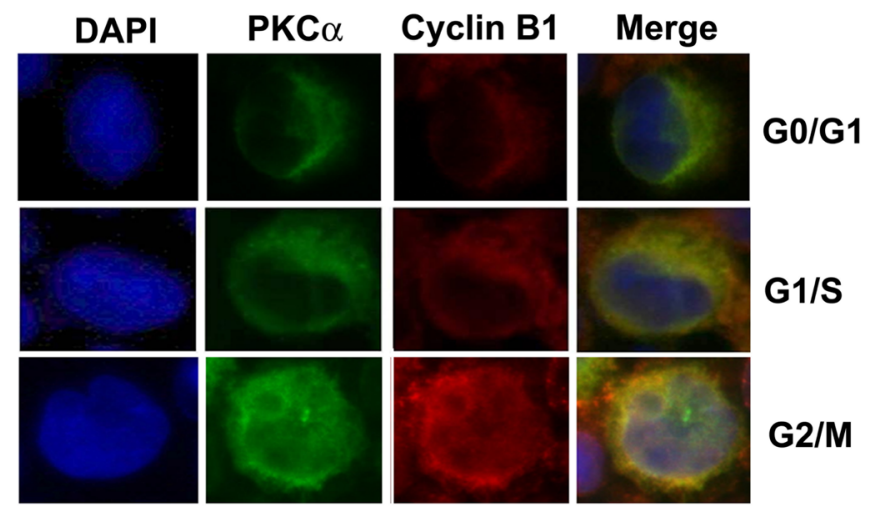

Figure 3: PKCa and Cyclin B1 accumulate into the nuclei and interact at G2/M. (a) Cells were synchronized in G0/G1 by HBSS (G0/G1), G1/S by complete RPMI 10\% FBS (G1/S) and G2/M by Nocodazole (G2/M). (b) Immunoblot analysis of total, nuclear and cytoplasmic lysates of cells synchronized at different cell cycle phases was performed to investigat PKC $\alpha$ and Cyclin B1 expression and localization during cell cycle. PKC $\alpha$ and Cyclin B1 increase and translocate into the nuclei during cell cycle, peaking at G2/M checkpoint. (c) Cells were synchronized as a) and analyzed using immunocytochemistry to study PKC $\alpha$ and Cyclin B1 localization. The two enzymes co-localize during cell cycle progression and accumulate into the nuclei in particular at G2/M transition.

(Continued) 


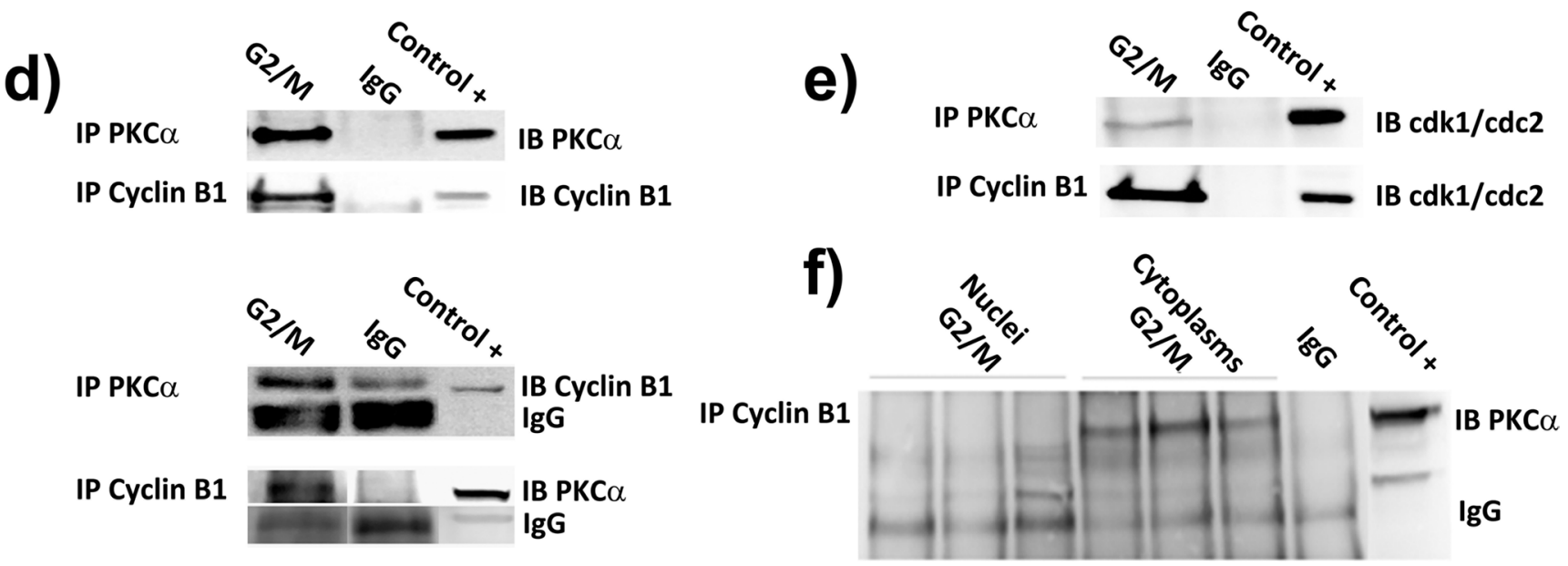

Figure 3: (d) Co-immunoprecipitations experiments in cells synchronized at $\mathrm{G} 2 / \mathrm{M}(\mathrm{G} 2 / \mathrm{M})$ indicated the possibility for $\mathrm{PKC} \alpha$

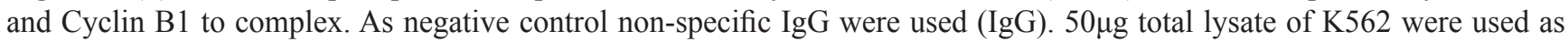
positive control (Control + ). To show that the experiments were performed correctly, immunoblots of the immunoprecipitated proteins are provided. All the experiments were performed more than four times. (e) Cells were blocked at G2/M checkpoint and PKC $\alpha$ or Cyclin B1 were immunoprecipitated. An antibody anti-cdk1/cdc2 was used to detect the capacity for both the proteins to interact with this kinase. (f) The interaction between Cyclin B1 and PKCa takes place in the cytoplasms. Nuclei and cytoplasms of cells synchronized in G2/M were separated. Cyclin B1 was immunoprecipitated and PKCa was detected via Western Blotting. The complex between the two enzymes was appreciable only in the cytoplasmic fractions of the cells. The experiment was repeated three times as shown in the figure.

G2/M and we found that Cyclin B1 and PKC $\alpha$ were able to interact in the cytoplasmic fraction (Figure $3 \mathrm{~F}$ ). These data indicated that the interaction between the two proteins could be very important in the prevention of Cyclin B1 degradation during cell cycle progression.

\section{Cyclin B1 nuclear accumulation is modulated by the changes of $\mathrm{PKC} \alpha$ expression}

As reported above, $\mathrm{PKC} \alpha$ and Cyclin B1 co-localize and interact, in particular during $\mathrm{G} 2 / \mathrm{M}$ progression. Both of these molecules can accumulate into the nucleus during this phase of the cell cycle, but how this mechanism works is still not well understood [24]. In these series of experiments, we showed that lack or increase of PKC $\alpha$, and its consequent minor or major nuclear translocation at mitosis, affected Cyclin B1 nuclear import. We silenced or overexpressed PKC $\alpha$ in cells treated with Nocodazole as previously described and we separated nuclei from cytoplasms. Silencing of PKCa led to a decrease of Cyclin B1 levels in cytoplasms and in nuclei of K562 cells synchronized at G2/M checkpoint (Figure 4A). On the contrary, overexpression of $\mathrm{PKC} \alpha$ drove to a higher accumulation of Cyclin B1 both into the nuclear and cytoplasmic fractions (Figure 4B). All these data were confirmed by immunocytochemistry experiments and using PKC inhibitor (Figure 4C and Supplementary Figure 7A and 7B). Taken together, these evidences indicated that the more PKC $\alpha$ translocates in the nucleus at $\mathrm{G} 2 / \mathrm{M}$ checkpoint the more nuclear accumulation of Cyclin B1 takes place in K562 cell line.

\section{Nuclear DAG increase is required for $\mathrm{PKC} \alpha$ and Cyclin B1 translocation into the nucleus}

In order to better understand the mechanism by which PKC $\alpha$ and Cyclin B1 accumulate into the nucleus at $\mathrm{G} 2 / \mathrm{M}$ checkpoint, we investigated nuclear DAG fluctuations during cell cycle progression of K562 cells. As already reported, nuclear amount of DAG peaks at G2/M, attracting PKCs to translocate into the nucleus $[6,15,17]$. Cells were synchronized at G1/S and G2/M as previously described. Total and nuclear samples were labeled with $\left[{ }^{3} \mathrm{H}\right]$-glycerol and lipids were extracted. The percentage of radioactivity corresponding to DAG was analyzed (see materials and methods for the complete protocol). Accordingly with other studies [6, 15, 17], we found a slight increase in DAG levels in total samples of cells synchronized at G2/M compared to G1/S cells. On the other hand, analyzing nuclear extracts, we observed a very high increase in nuclear DAG in G2/M cells compared to G1/S cells (Figure 5A). This evidence suggested DAG as the molecule responsible for Cyclin B1 and PKC $\alpha$ nuclear translocation. Then, in order to simulate DAG effects on PKC $\alpha$ nuclear import, we treated the cells with PMA (100nM) for 30 minutes, as already described [41, 42]. Nuclear fractions of G2/M cells treated with PMA showed an increase of Cyclin B1 and PKC $\alpha$ levels compared to 


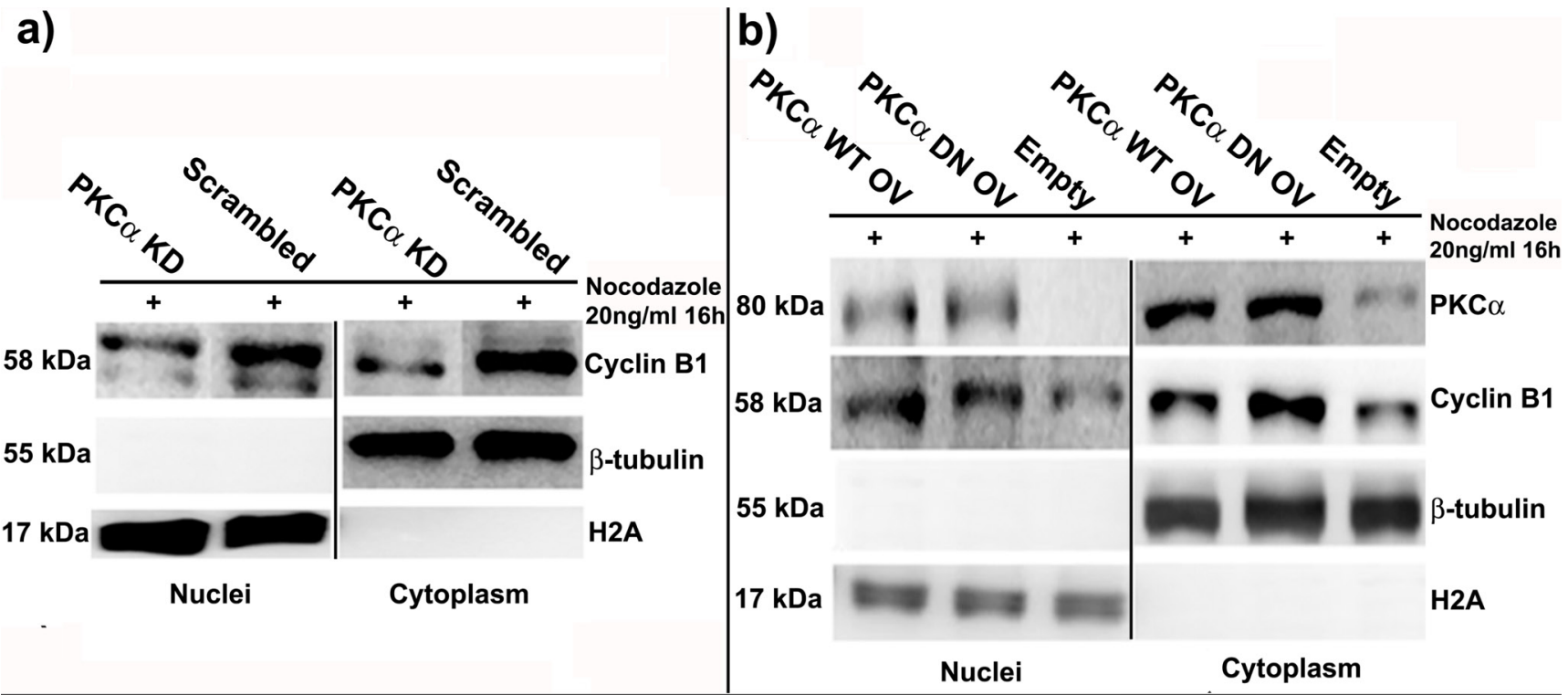

c)

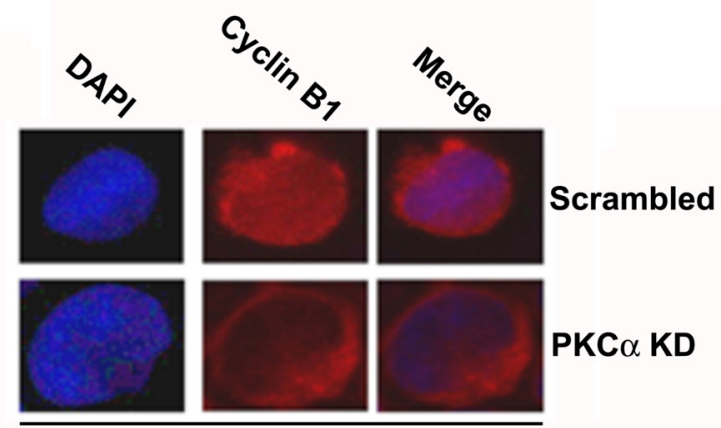

Nocodazole $16 \mathrm{~h} 20 \mathrm{ng} / \mathrm{ml}$
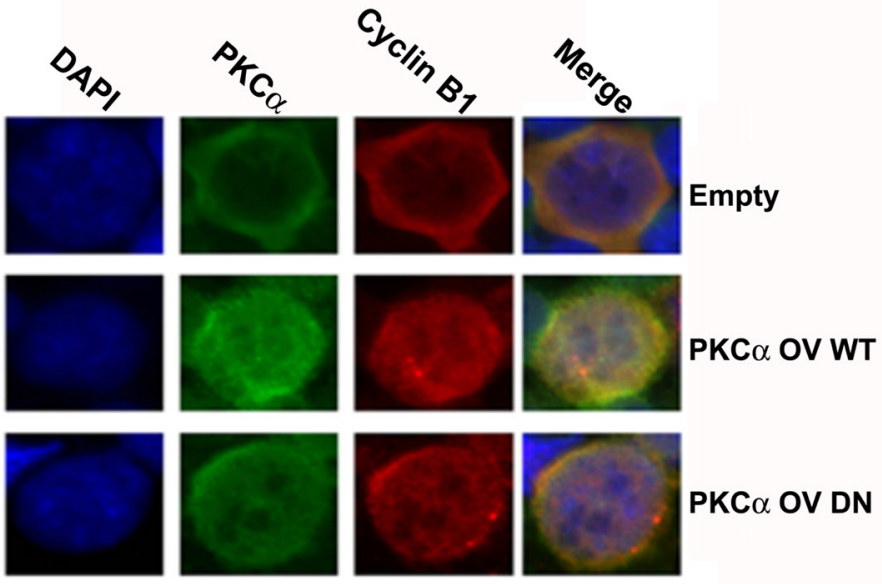

Figure 4: PKCa silencing or overexpression modulate the amount of Cyclin B1 in the nucleus at G2/M checkpoint. (a) PKC $\alpha$ was silenced and, 48 hours later, cells were synchronized using Nocodazole. A Scrambled siRNA was used as control (Scrambled). Then, nuclei and cytoplasms were separated and Cyclin B1 localization was investigated. Cyclin B1 decreases both in the cytoplasms and in the nuclei. (b) PKC $\alpha$ was overexpressed using WT and DN vectors and cells were treated with Nocodazole for 6 hours. An Empty vector (Empty) was used as control. Cyclin B1 increases both in the nuclei and the cytoplasms. (c) Cells were treated as reported in a) and b) and immunocytochemistry was performed to study the localization of Cyclin B1.

the controls. However, as known, DAG is the product of the action of the Phospholipases C (PLC) activity, which, hydrolyzing Phosphatidylinositol 4, 5-bisphosphate ( $\mathrm{PIP}_{2}$ ), produces DAG and Inositol triphosphate $\left(\mathrm{IP}_{3}\right)$ [43-45]. Thus, in order to reduce DAG production, we treated our cells with a potent PLC inhibitor, U73122, at a final concentration of $10 \mu \mathrm{M}$ for 16 hours. Nuclear amount of $\mathrm{PKC} \alpha$ in $\mathrm{G} 2 / \mathrm{M}$ synchronized cells was analyzed. We found a strong decrease of nuclear PKC $\alpha$ in cells treated with U73122 compared to the controls. Notably, Cyclin B1 nuclear accumulation was inhibited too (Figure 5B). Taken together, these data indicated DAG as an important factor for nuclear import of $\mathrm{PKC} \alpha$, which, in turn, seemed to stimulate Cyclin B1 nuclear accumulation during G2/M progression.

\section{Nuclear PLC $\beta 1$ is responsible for DAG regulation during cell cycle progression}

In this series of experiments, we screened some of the most expressed PLC isoforms in K562 cells, in order to understand which one was responsible for nuclear DAG oscillations during cell cycle. Then, we synchronized the cells at the different phases of cell cycle and we separated nuclei from cytoplasms. Interestingly, among the PLC isoforms studied, only PLC $\beta 1$ resulted mainly localized 

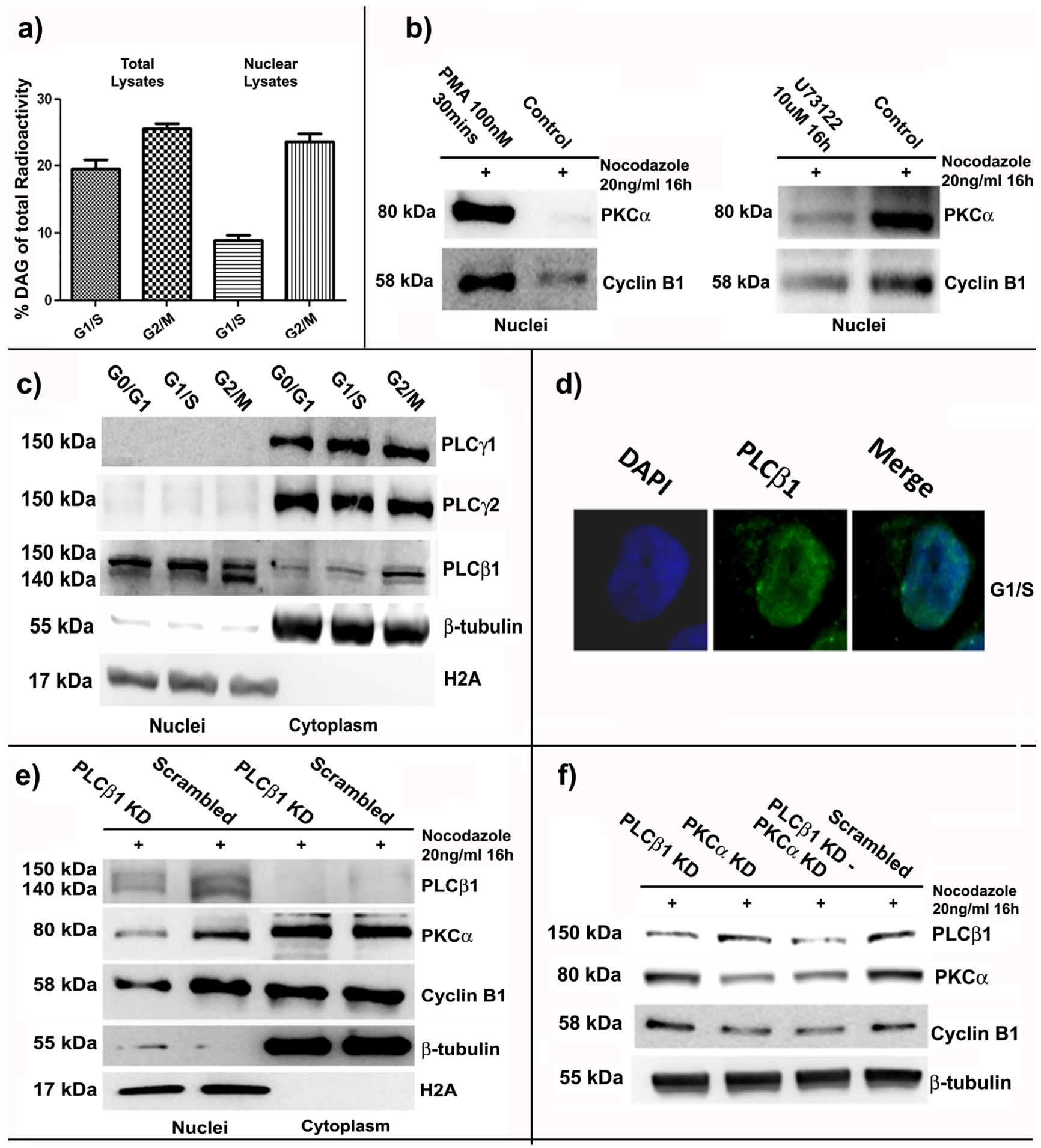

Figure 5: PLC $\beta 1$ related nuclear DAG increase at G2/M stimulates nuclear translocation of PKC $\alpha$ and Cyclin B1. (a) Cells were synchronized at G1/S and G2/M and nuclear or total samples were treated to extract lipids. The percentage of radioactivity corresponding to DAG amount was investigated. Nuclear DAG increased at G2/M. (b) Cells were treated with PMA (PMA) or U73122 (U73122) and synchronized at G2/M. Nuclear accumulation of PKC $\alpha$ and Cyclin B1 resulted linked to DAG fluctuations during cell cycle. (c) Cells were synchronized at G0/G1, G1/S and G2/M and the localization of different PLCs was investigated. PLC $\beta 1$ was the only one mainly localized into the nucleus. (d) Immunocytochemistry was performed to further study PLC $\beta 1$ localization. (e) PLC $\beta 1$ was silenced (PLC $\beta 1 \mathrm{KD}$ ) and cells were synchronized at G2/M. A Scrambled siRNA was used as control (Scrambled). PKC $\alpha$ and Cyclin B1 had minor nuclear accumulation in PLC $\beta 1$ knock-down conditions. (f) PLC $\beta 1$ (PLC $\beta 1$ KD), PKC $\alpha$ (PKC $\alpha$ KD) or both the molecules (PLC $\beta 1 \mathrm{KD}-\mathrm{PKC} \alpha \mathrm{KD}$ ) were silenced. After synchronization at G2/M phase, immunoblot analyses showed that double knock-down condition had the same effects on Cyclin B1 expression than PKC $\alpha$ silencing alone. PLC $\beta 1$ silencing did not affect Cyclin B1.

(Continued) 


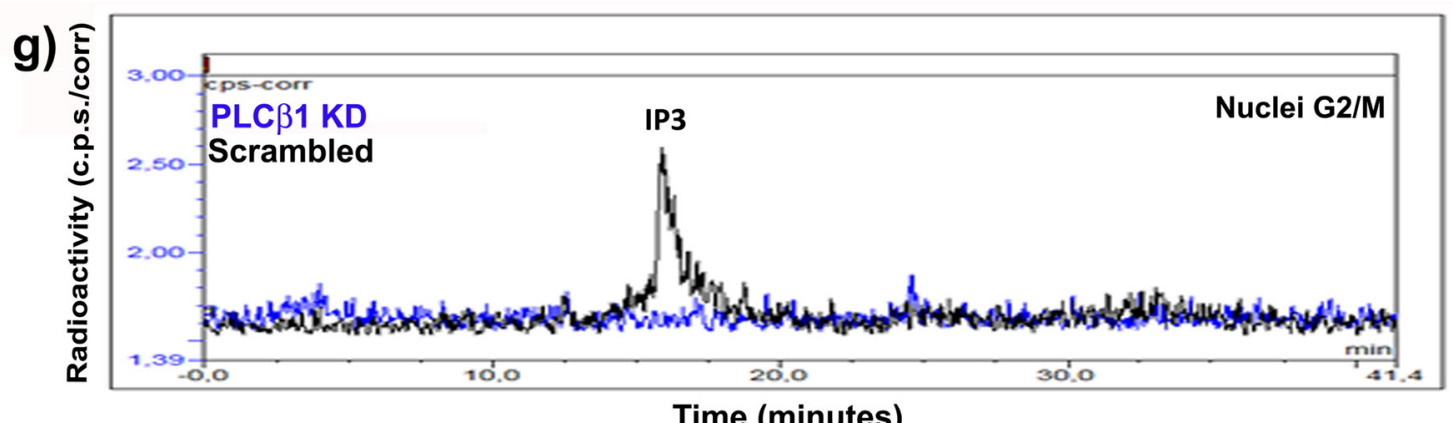

Figure 5: (g) PLC $\beta 1$ was silenced and cells synchronized at G2/M. Nuclear production of $\mathrm{IP}_{3}$ decreased after silencing of PLC $\beta 1$. All the experiments were repeated at least three times.

into the nucleus of K562 cells (Figure 5C-D). Next, we transiently silenced PLC $\beta 1$ (PLC $\beta 1 \mathrm{KD}$ ) and, 48 hours later, we synchronized the cells at G2/M checkpoint. We used more than a single siRNA to silence PLC $\beta 1$ expression to avoid any possible off-target effect and the experiments were repeated more than three times (see materials and methods). Notably, we observed a minor accumulation of both PKC $\alpha$ and Cyclin B1 in PLC $\beta 1$ knock-down cells compared to the controls (Scrambled) (Figure 5E). Moreover, PLC $\beta 1$ and PKC $\alpha$ resulted to be part of the same pathway. We silenced PLC $\beta 1$ (PLC $\beta 1 \mathrm{KD}), \mathrm{PKC} \alpha(\mathrm{PKC} \alpha \mathrm{KD})$ or both the molecules (PLC $\beta 1 \mathrm{KD}-\mathrm{PKC} \alpha \mathrm{KD}$ ). A Scrambled siRNA was used as control (Scrambled). 48 hours after the transfections, cells were synchronized at G2/M. Interestingly, double knock-down of PKC $\alpha$ and PLC $\beta 1$ had the same effects on Cyclin B1 expression than the silencing of PKC $\alpha$ alone. In addition, PLC $\beta 1$ silencing did not affect Cyclin B1 (Figure 5F). Finally, in order to further confirm that PLC $\beta 1$ silencing reduced its nuclear activity and, therefore, the production of DAG, we analyzed the production of $\mathrm{IP}_{3}$ in nuclear lysates of G2/M cells using a PLC assay previously described [46]. According to our findings, nuclear fractions characterized by PLC $\beta 1$ knock-down showed a strong decrease in $\mathrm{IP}_{3}$ amount compared to the controls (Figure 5G). These findings demonstrated the importance of nuclear PLC $\beta 1$ for the oscillations of DAG, related to the different cell cycle phases.

\section{DISCUSSION}

Although the involvement of Protein Kinases C in the regulation of cell cycle progression has already been widely investigated, little has been reported about a possible connection between PKC signalling and Cyclin $\mathrm{B} 1 / \mathrm{Cdk} 1$. In particular, even if other classes of Cyclins (D, E and A) can be modulated by different isoforms of PKCs, Cyclin B1 was not linked to any of them so far $[2,4,12,47]$. Previous studies from our laboratory indicated important roles for PKC $\alpha$ in cell cycle regulation.
As a matter of fact, we found that PKC $\alpha$ was able to translocate into the nuclei of murine erythroleukemia cells (MEL) at the beginning of mitosis [19]. Here, it phosphorylated Lamin B1, stimulating its disassembly and, then, the progression through $\mathrm{G} 2 / \mathrm{M}$ phase. More recently, we demonstrated that lipid signalling could be involved in the regulation of Cyclin D3 and, in turn, of cell proliferation in human erythroleukemia cells, K562. Indeed, we observed that overexpression of PLC $\beta 1$ drove to an up-modulation of Cyclin D3 and a down-regulation of PKC $\alpha$ expression [12]. This was followed by an accumulation of cells at G1/S transition. In particular, silencing of $\mathrm{PKC} \alpha$ led to a very similar up-regulation of Cyclin D3 compared to PLC $\beta 1$ overexpression [12]. Taken together, these evidences suggested an important role for PKC $\alpha$ in cell cycle modulation of K562 cell line. Moreover, as up-modulation of D-type cyclins is commonly linked to down-regulation of the B-type isoforms, we decided to understand if $\mathrm{PKC} \alpha$ could be also involved in G2/M progression targeting Cyclin B1 [21]. In this study, we described a novel and peculiar DAGdependent mechanism through which $\mathrm{PKC} \alpha$ regulates Cyclin B1, leading to effects on G2/M transition. Indeed, using different $\mathrm{PKC}$ inhibitors, we observed a strong decrease of Cyclin B1 expression consequent to PKCs down-regulation. Notably, inhibiting only the activity of PKCs, we did not find any effect on Cyclin B1 expression. As the effects of two of the inhibitors that we used, Go6976 and Go6983, have already been widely described in literature [33], surprising was the capacity of the PKC inhibitor to downregulate the levels of conventional PKCs in our cell model (at $1 \mu \mathrm{M}$ it seemed not specific only for $\mathrm{PKC} \beta$, see materials and methods). As the gene expression of the enzymes was not targeted, this peculiar action on PKCs was probably due to side effects on other proteins involved in PKC life cycle. However, this mechanism must be further studied in the future. Moreover, treating the cells with PMA, in order to stimulate the PKC signalling, we obtained, a strong decrease in PKC expression, followed by a drop of Cyclin $\mathrm{B} 1$ levels. If PKC 
decrease was related to their iper-activation by PMA, as explained elsewhere [35-37], Cyclin B1 down-regulation appeared to be related to the amount of PKCs present in the cells. In particular, to avoid any oscillation of Cyclin B1 expression, all the experiments were performed synchronizing the cells at the same cell cycle phase. As K562 cell line is characterized by the presence of only two DAG-dependent PKC isoforms, PKC $\alpha$ and PKC $\beta I$ $[12,36]$, we focused on these two molecules. Experiments of RNA interference showed that only in PKC $\alpha$ knockdown conditions the levels of Cyclin B1 drop in the cells. This led to an accumulation of the cells at G2/M, which could be related to the lack of Cyclin B1 caused by PKC $\alpha$ silencing. Indeed, accordingly to literature, a high decrease of Cyclin B1 could interfere with the transition through the $\mathrm{G} 2 / \mathrm{M}$ phase of cell cycle [38]. In addition, this mechanism resulted independent by the kinase activity of PKC $\alpha$. Overexpression of a Dominant Negative (DN) mutant of PKC $\alpha$ drove to the same up-modulation of Cyclin B1 and cell cycle progression than the Wild Type isoform (WT). Next, investigating this regulatory mechanism, we found that $\mathrm{PKC} \alpha$ did not regulate the gene expression of Cyclin B1, but it affected its degradation. Notably, experiments performed using the proteasome inhibitor MG-132 indicated that Cyclin B1 degradation raised with lack of $\mathrm{PKC} \alpha$. Our findings were supported by $\mathrm{p} 21$ up-modulation during PKCa silencing. Indeed, the expression of this $\mathrm{Cip} / \mathrm{Kip}$ inhibitor has already been described to increase during Cyclin B1 degradation [40]. Next, we decided to investigate the behavior of these two molecules during cell cycle progression. They resulted able to co-localize during the different cell cycle phases, accumulating into the nucleus, especially at G2/M. Next, experiments of co-immunoprecipitation indicated the possibility for the two proteins to interact. In addition, as further demonstration of that, $\mathrm{PKC} \alpha$ resulted able to immunoprecipitated also with $\mathrm{cdk} 1 / \mathrm{cdc} 2$, the kinase which interacts with Cyclin B1 and regulates $\mathrm{G} 2 / \mathrm{M}$ progression of the cell cycle [20-28]. In particular, the complex appeared to be located in the cytoplasmic fraction and to take place along the cell cycle. These evidences suggested a possible role for $\mathrm{PKC} \alpha$ in preserving Cyclin B1 from degradation thanks to its physical interaction with it. Moreover, $\mathrm{PKC} \alpha$ nuclear translocation during mitosis seemed to modulate Cyclin B1 import. Indeed, silencing or overexpression of PKC $\alpha$ led to an important modulation of the amount of nuclear Cyclin B1. Then, we decided to understand which was the factor that promoted PKC $\alpha$ nuclear import during mitosis. We observed that nuclear DAG amount, as already reported in other models [14-18], raised in the nucleus of K562 cells at G2/M. Considering it as the possible trigger for $\mathrm{PKC} \alpha$ and $\mathrm{Cyclin} \mathrm{B} 1$ nuclear import, we decided to simulate its accumulation using PMA, as already described by other studies $[41,42]$. This treatment increased the accumulation of both $\mathrm{PKC} \alpha$ and Cyclin $\mathrm{B} 1$ in the nuclei of the cells. On the contrary, in order to limit DAG production, as Phospholipases C (PLC) are a family of proteins able to hydrolyze Phosphatidylinositol 4,5-bisphosphate $\left(\mathrm{PIP}_{2}\right)$, producing $\mathrm{DAG}$ and $\mathrm{IP}_{3}$ [44-46], we inhibited their activity treating the cells with a PLC inhibitor, U73122. Interestingly, we found a minor nuclear accumulation of the two proteins. Next, we investigated which PLC isoform could be responsible for DAG production during cell cycle progression. Notably, we noticed that the only isoform mainly localized in the nuclei was PLC $\beta 1$, capable to modulate nuclear import of $\mathrm{PKC} \alpha$ and Cyclin B1 during mitosis. Indeed, silencing this isozyme led to the same minor accumulation in the nuclei of the two molecules observed using the U73122 inhibitor. In particular, Cyclin B1 resulted to be downstream of the $\mathrm{PLC} \beta 1 / \mathrm{PKC} \alpha$ pathway. Indeed, experiments of double knock-down of the two molecules did not have any higher effect on Cyclin B1 expression than the PKC $\alpha$ silencing alone. Finally, we proved that PLC $\beta 1$ silencing inhibited the production of $\mathrm{IP}_{3}$ in the nucleus of G2/M cells. These results indicated that the lipase was responsible of lipid changes during cell cycle progression. What emerges by our study is a novel mechanism, through which $\mathrm{PKC} \alpha$ results fundamental for stability and nuclear import of Cyclin B1 during G2/M progression. This process is mediated by cell cycle related nuclear DAG fluctuations, which are due to the activity of nuclear PLC $\beta 1$.

\section{MATERIALS AND METHODS}

\section{Cell culture}

Human erythroleukemia cells (K562) were grown in RPMI 1640 (Sigma Aldrich) supplemented with 10\% heatinactivated fetal bovine serum (FBS) and L-glutamine/ streptomycin $(1 \times)$. Cells were treated with the following compounds: Phorbol 12-myristate 13-acetate (PMA, Sigma Aldrich) at a final concentration of $50-100 \mathrm{nM}$ for $30 \mathrm{mins}$ or 16 hours, U73122 (Sigma Aldrich, PLC inhibitor) at $10 \mu \mathrm{M}$ for 16 hours, with Go6976 and Go6983 at $1 \mu \mathrm{M}$ (Sigma Aldrich, PKC inhibitor) and with 3-(1-(3-imidazol1-ylpropyl)-1H-indol-3-yl)-4-anilino-1H-pyrrole-2,5-dione anilinomonoindolylmaleimide (Calbiochem, PKC inhibitor [34]) at $1 \mu \mathrm{M}$ for 24 hours. Finally, MG-132 (Sigma Aldrich, proteasome inhibitor) was used at a final concentration of $15 \mu \mathrm{M}$ for 2 hours.

\section{Cell synchronization}

Cells were collected as described below for the experiments: (1) G1/S cells: proliferating cells were cultured in complete RPMI 1640 FBS 10\%; (2) G2/M blocked cells: growing cells were treated with Nocodazole (Sigma Aldrich) at a final concentration of $20 \mathrm{ng} / \mathrm{ml}$ for $16 \mathrm{~h}$; (3) G0/G1 cells: growing cells were starved in Hank's Balanced Salt Solution (HBSS, Sigma Aldrich) for 16 hours. In experiments of PKC $\alpha$ overexpression, cells 
were partially stimulated to undergo G2/M accumulation adding Nocodazole for 6 hours at a final concentration of $20 \mathrm{ng} / \mathrm{ml}$

\section{Western blot analysis}

Cells were collected by centrifugation, washed in PBS and lysed in mPER lysis buffer (BIORAD) containing protease inhibitors (Thema Ricerca). Samples were separated on SDS-PAGE and electro-transferred to nitrocellulose membranes. Membranes were washed in PBS-0.1\%Tween-20 (PBS/T) and nonspecific binding sites were blocked by incubation in blocking buffer (PBS/T with 5\% w/v non-fat dry milk) for $1 \mathrm{~h}$ at room temperature. After several PBS/T-washes, membranes were incubated with primary antibodies overnight at $4^{\circ} \mathrm{C}$. Membranes were washed again, then incubated with peroxidase conjugated secondary antibodies diluted in $\mathrm{PBS} / \mathrm{T}$ for $1 \mathrm{~h}$ at room temperature. Proteins were detected by incubating membranes in enhanced chemiluminescence detection system (ECL, Thema Ricerca). Antibodies were as follows: PLC $\beta 1$, Cyclin D3, Cyclin B1, PKC $\alpha$, PKC $\beta I I$, Lamin A/C, from Santa Cruz, PKC $\alpha$ and Cyclin B1, phospho-Cyclin B1 Ser133, phospho-Cyclin B1 Ser147, Cdc25c, Cdk1/cdc2, phospho-Cdk1/cdc2 Tyr15, Cdk7 from Cell Signaling technology and $\beta$-tubulin from Sigma Aldrich. Analysis with an antibody for $\beta$-tubulin demonstrated equal protein loading.

\section{Flow cytometric analysis of cell cycle}

For FACS analysis $1 \times 10^{6}$ cells were collected by centrifugation at $1,200 \mathrm{rpm}$ for $5 \mathrm{~min}$ at $4^{\circ} \mathrm{C}$ and washed twice in ice-cold PBS. Cells were fixed (and permeabilized) with $-20^{\circ} \mathrm{C}$ cold $70 \%$ ethanol overnight at $4^{\circ} \mathrm{C}$. Fixed cells were, then, washed in PBS twice and resuspended in $1 \mathrm{ml}$ of staining solution $(40 \mu \mathrm{g} / \mathrm{ml}$ propidium iodide and $100 \mu \mathrm{g} / \mathrm{ml}$ RNase $\mathrm{A}$ in PBS). The samples were incubated for at least $30 \mathrm{~min}$ at room temperature in the dark. FACS analysis was performed, and the percentage of cells in different phases of the cell cycle was assessed using a FC500 flow cytometer equipped with cxp software (Beckman Coulter Inc.). At least 10,000 events per sample were acquired.

\section{Cell transfections}

Cells were transfected with full-length DNA vectors for human $\mathrm{PKC} \alpha$ (Addgene, plasmid number 21232 and 21235) [48] using empty pcDNA/2.1 plasmid (Invitrogen) as control. Overexpressions were performed using Lipofectamine 2000 from Invitrogen. Cells were seeded at a cell density of $5 \times 10^{5} / \mathrm{ml}$ in 6 -well plates, to which was added the mix of Lipofectamine 2000 (Life Technologies) and right vectors, following manufacturer's instructions. The expression of PKC $\alpha$, PKC $\beta I I$ and PLC $\beta 1$ was silenced by RNAi at a final concentration of 50nM using the electroporation assay kit by Thema Ricerca (program T-16) and Lipofectamine RNAiMAX (Life Technologies) as indicated by the manufacturers' instructions. The following siRNAs were used: in order to silence PLC $\beta 1$ s23358 and s23359 (Applied Biosystems), to silence PKC $\alpha$ s11092, s11093 and s11094 (Applied Biosystems), to silence PKC $\beta$ II s11095 (Applied Biosystems). As negative control a mix of Silencer Select Negative Control \#1 and \#2 siRNAs (Applied Biosystems).

\section{Nuclear extraction and purification}

Cells were collected, centrifuged and washed in PBS $1 \mathrm{X}$. PBS $1 \mathrm{X}$ was accurately removed, and the pellets were resuspended in $1 \mathrm{ml}$ of TM2 buffer $(10 \mathrm{mM}$ Tris- $\mathrm{HCl}$ $\mathrm{pH} 7.4,2 \mathrm{mM} \mathrm{MgCl}_{2}$ ) for 2 minutes. Then, Triton $0.6 \%$ was added and everything was passed twice through a syringe with a $22 \frac{1}{2}$ gauge needle. Next, $\mathrm{MgCl} 23 \mathrm{mM}$ was added to the solution, which was centrifuged for 10 mins at $0.8 \mathrm{rpm}$. The nuclear pellets were washed twice in TM5 buffer (10 mM Tris- $\mathrm{HCl} \mathrm{pH} 7.4,5 \mathrm{mM} \mathrm{MgCl}$ ), while the supernatant was transferred in a new vial and used like a cytoplasmic control.

\section{Immunoprecipitation}

Cells were lysed in mPER lysis buffer (BIORAD) containing protease inhibitors (Thema Ricerca). $500 \mu \mathrm{g}$ of proteins were pre-cleared adding $20 \mu \mathrm{l}$ of Protein $\mathrm{A} / \mathrm{G}$ PLUS-Agarose (Santa Cruz) for 1 hour at $4{ }^{\circ} \mathrm{C}$. Then, beads were centrifuged and the supernatant transferred in another vial. $500 \mu \mathrm{l}$ of protein lysates were incubated over/ night with the appropriate primary antibodies on wheels at $4^{\circ} \mathrm{C}$. The day after, $25 \mu \mathrm{l}$ of Protein A/G PLUS-Agarose were added for $1 \mathrm{~h}$ at $4^{\circ} \mathrm{C}$. Beads were centrifuged and pellets washed 3 times with mPER. Immuno-complexes were resuspended in loading buffer $(4 \mathrm{X})$, boiled at $95^{\circ} \mathrm{C}$ for 5 minutes, resolved on SDS/PAGE and transferred on nitrocellulose. After incubation with the indicated antibodies, antibody-protein interactions were detected with enhanced chemiluminescence detection system (ECL, Thema Ricerca). As positive control $50 \mu \mathrm{g}$ of proteins from total lysates of K562 were loaded on SDS/PAGE gel.

\section{Immunofluorescence microscopy}

Cells were seeded on electrostatically charged glass slides using a Shandon Cytospin (Thermo Electron Corporation, Pittsburgh, PA, USA) at low acceleration and $200 \mathrm{rpm}$ for $5 \mathrm{~min}$. Slides were fixed in $4 \%$ paraformaldehyde at $37^{\circ} \mathrm{C}$ for $10 \mathrm{~min}$ and permeabilized with $0.15 \%$ Triton $\mathrm{X}-100$ in PBS for $8 \mathrm{~min}$. Then slides were blocked with PBS containing 5\% BSA for $1 \mathrm{~h}$. Incubation with monoclonal anti-PKC $\alpha$ (1:100) (Santa Cruz) and Cyclin B1 (1:100) (Santa Cruz) was 
performed overnight at $4^{\circ} \mathrm{C}$ in blocking medium and then with FITC-conjugated anti-mouse immunoglobulin $\mathrm{G}(\mathrm{IgG})$ antibody (1:200) or Cy3-conjugated anti-rabbit IgG antibody (1:100) (Sigma-Aldrich) for $1 \mathrm{~h}$ at room temperature. Slides were washed 3 times for $10 \mathrm{~min}$ at room temperature with $\mathrm{PBS} /$ Tween and mounted with a DAPI anti-fade reagent in glycerol (Molecular Probes, Eugene, OR, USA). Images were taken on a Zeiss Axio ImagerZ1 microscope, equipped with $60 \mathrm{X} / \mathrm{NA} 1.4$ optics and Apotome apparatus, coupled to a computer driven Zeiss AxioCam digital camera (MRm), using Zeiss Axio Vision 4.4 software (Carl Zeiss, Oberkochen, Germany).

\section{RNA extraction, retrotranscription and real-time PCR analysis}

RNA extraction, retrotranscription and real-time PCR were performed as already described [12]. Gene expression were assessed using for $\mathrm{PKC} \alpha$ the probe Hs00925193_m1, for Cyclin B1 the Hs00820463_g1 and for PLC $\beta 1$ the Hs00248563_m1 (Applied Biosystems).

\section{Cell Counting}

To determine cell growth, cells were synchronized using Nocodazole and, 24 hours later, the block was removed seeding them in complete RPMI 10\% FBS at a cell density of $1 \times 10^{5} / \mathrm{ml}$ in 6 -well plates. Growth curves were determined by direct counting of cells harvested for 24, 48 and $72 \mathrm{~h}$ after seeding. Viable cells were handly counted by a hemocytometer using $0.2 \%$ Trypan Blue.

\section{Statistical analysis}

Statistical analyses were performed by Student t-test, using GraphPad Prism (GraphPad Software Inc. version.6) $(* P<0.05, * * P<0.001, * * * P<0.0001)$.

\section{Quantification of DAG amount}

K562 cells were cultured and synchronized as previously described. Nuclei or intact cells were labeled with $\left[{ }^{3} \mathrm{H}\right]$-glycerol $\left(10 \mu \mathrm{Ci} / \mathrm{ml} / 1 \times 10^{6}\right.$ cells $)$ for 90 minutes. Next, nuclei and total cells were precipitated with $10 \%$ TCA and, then, 10 volumes of chloroform/ methanol/concentrated $\mathrm{HCl}$ (300:300:1.5) were added and lipids extracted for 20 hours at $4^{\circ} \mathrm{C}$. After centrifugation, supernatants were preserved and the pellets were re-extracted twice with 10 volumes of chloroform/ methanol/concentrated $\mathrm{HCl}$ (400:200/1.5). The combined supernatants were dried under steam of nitrogen and lipids were dissolved in 100ul of chloroform and washed three times in 4 volumes of chloroform/methanol/water (3:48:47). Finally the samples were dried under a steam of nitrogen and $\left[{ }^{3} \mathrm{H}\right]$-labelled lipids were analyzed by TLC on silica gel 60 plates developed with ether/exane/NH4
(50:50:0.25). TLC plates were sprayed with Enhancer (Du Pont, NEN) and fluorographed at $-80^{\circ} \mathrm{C}$. Spots corresponding to lipids were scraped off, extracted with $1.5 \mathrm{ml}$ of $0.6 \mathrm{~N} \mathrm{HCl-Methanol} \mathrm{(60:40} \mathrm{by} \mathrm{volume)} \mathrm{for}$ 48 hours with gentle stirring and counted with a liquid scintillation counter using $9 \mathrm{ml}$ of Packard Pico-Fluor 40 scintillation cocktail.

\section{PLC assay}

The activity of nuclear PLC $\beta 1$ was assessed using a protocol described elsewhere [46].

\section{ACKNOWLEDGEMENTS}

This work was supported by Italian MIUR-FIRB, Human Proteome Net.

\section{Conflict of interest}

The authors declare no conflict of interest.

\section{ABBREVIATIONS}

PKC, Protein Kinase C; PLC, Phospholipase C; DAG, diacylglycerol; $\mathbf{I P}_{3}$, inositol 1,4,5-trisphosphate; $\mathbf{C a}^{2+}$, Calcium; Cdk, cyclin-dependent kinase; CRS, cytoplasmic retention signal; NLS, nuclear localization signal; PMA, phorbol-12-myristate-13-acetate.

\section{REFERENCES}

1. Newton AC. Protein kinase C: poised to signal. Am J Physiol Endocrinol Metab. 2010; 298:E395-402.

2. Poli A, Mongiorgi S, Cocco L, Follo MY. Protein Kinase C involvement in cell cycle modulation. Biochem Soc Trans. 2014; 42:1471-1476.

3. Rosse C, Linch $\mathrm{M}$, Kermorgant S, Cameron AJ, Boeckeler K, Parker PJ. PKC and the control of localized signal dynamics. Nat Rev Mol Cell Biol. 2010; 11:103-112.

4. Black AR, Black JD. Protein kinase C signaling and cell cycle regulation. Front Immunol. 2012; 3:423.

5. Lange L, Keppner-Witter S, Grigat J, Spankuch B. Combinatorial inhibition of Plk1 and PKC $\beta$ in cancer cells with different p53 status. Oncotarget. 2014; 5:2263-2275.

6. Martelli AM, Faenza I, Billi AM, Fala F, Cocco L, Manzoli L. Nuclear protein kinase C isoforms: key players in multiple cell functions? Histol Histopathol. 2003; 18:1301-1312.

7. McCubrey JA, Steelman LS, Chappell WH, Sun L, Davis NM, Abrams SL, Franklin RA, Cocco L, Evangelisti C, Chiarini F, Martelli AM, Libra M, Candido S, Ligresti G, Malaponte G, Mazzarino MC, et al. 
Advances in targeting signal transduction pathways. Oncotarg et. 2012; 3:1505-1521.

8. De Vita F, Riccardi M, Malanga D, Scrima M, De Marco C, Viglietto G. PKC-dependent phosphorylation of p27 at T198 contributes to p27 stabilization and cell cycle arrest. Cell Cycle. 2012; 11:1583-1592.

9. Guan L, Song K, Pysz MA, Curry KJ, Hizli AA, Danielpour D, Black AR, Black JD. Protein kinase C-mediated down-regulation of cyclin D1 involves activation of the translational repressor 4E-BP1 via a phosphoinositide 3-kinase/Akt-independent, protein phosphatase 2A-dependent mechanism in intestinal epithelial cells. J Biol Chem. 2007; 282:14213-14225.

10. Walker JL, Castagnino P, Chung BM, Kazanietz MG, Assoian RK. Post-transcriptional destabilization of p21/ cip1 by protein kinase C in fibroblasts. J Biol Chem. 2006; 281:38127-38132.

11. Haughian JM, Reno EM, Thorne AM, Bradford AP. Protein kinase $\mathrm{C}$ alpha-dependent signaling mediates endometrial cancer cell growth and tumorigenesis. Int J Cancer. 2009; 125:2556-2564.

12. Poli A, Faenza I, Chiarini F, Matteucci A, McCubrey JA, Cocco L. K562 cell proliferation is modulated by PLC $\beta 1$ through a PKC $\alpha$-mediated pathway. Cell Cycle. 2013; 12:1713-1721.

13. Bavelloni A, Poli A, Fiume R, Blalock W, Matteucci A, Ramazzotti G, McCubrey JA, Cocco L, Faenza I. PLCbeta 1 regulates the expression of miR-210 during mithramycin-mediated erythroid differentiation in K562 cells. Oncotarget. 2014; 5:4222-4231.

14. Follo MY, Faenza I, Piazzi M, Blalock WL Manzoli L, McCubrey JA, Cocco L. Nuclear PI-PLC $\beta 1$ : an appraisal on targets and pathology. Adv Biol Reg. 2014; 54:2-11.

15. Goss VL, Hocevar BA, Thompson LJ, Stratton CA, Burns DJ, Fields AP. Identification of nuclear beta II protein kinase $\mathrm{C}$ as a mitotic lamin kinase. Journal of Biological Chemistry. 1994; 269:19074-19080.

16. Irvine RF. Nuclear lipid signalling. Nat Rev Mol Cell Biol. 2003; 4:349-360.

17. Divecha N, Banfic H, Treagus JE, Vann L, Irvine RF, D'Santos C. Nuclear diacylglycerol, the cell cycle, the enzymes and a red herring (or how we came to love phosphatidylcholine). Biochem Soc Trans. 1997; 25:571-575.

18. Sun B, Murray NR, Fields AP. A role for nuclear phosphatidylinositol-specific phospholipase $\mathrm{C}$ in the $\mathrm{G} 2 / \mathrm{M}$ phase transition. J Biol Chem. 1997; 272:26313-26317.

19. Fiume R, Ramazzotti G, Teti G, Chiarini F, Faenza I, Mazzotti G, Billi AM, Cocco L. Involvement of nuclear PLC $\beta 1$ in lamin B1 phosphorylation and G2/M cell cycle progression. Faseb J. 2009; 23:957-966.

20. Dirila MK, Ratnacarama CK, Padmakumarb VC, Duc T, Wasserc M, Coppola V, Tessarollo L, Kaldisa P. Cyclin-dependent kinase 1 (Cdk1) is essential for cell division and suppression of DNA replication but not for liver regeneration. Proc Natl Acad Sci USA. 2012; 109:3826-3831.

21. Vermeulen K, Van Bockstaele DR, Berneman ZN. The cell cycle: a review of regulation, deregulation and therapeutic targets in cancer. Cell Prolif. 2003; 36:131-149.

22. Murray AW. Recycling the cell cycle: cyclins revisited. Cell. 2004; 116:221-234.

23. Bloom J, Cross FR. Multiple levels of cyclin specificity in cell-cycle control. Nature Reviews Molecular Cell Biology. 2007; 8:149-160.

24. Gavet O, Pines J. Progressive activation of CyclinB1-Cdk1 coordinates entry to mitosis. Developmental cell. 2010; 18:533-543.

25. Pagliuca FW, Collins MO, Choudhary JS. Coordinating cell cycle progression via cyclin specificity. Cell Cycle. 2011; 10:4195-4196.

26. Jackman M, Lindon C, Nigg EA, Pines J. Active cyclin B1-Cdk1 first appears on centrosomes in prophase. Nat Cell Biol. 2003; 5:143-148.

27. Takizawa CG, Morgan DO. Control of mitosis by changes in the subcellular location of cyclin-B1-Cdk1 and Cdc25C. Current Opinion in Cell Biology. 2000; 12:658-665.

28. Hagting A, Jackman M, Simpson K, Pines J. Translocation of cyclin B1 to the nucleus at prophase requires a phosphorylation-dependent nuclear import signal. Current Biology. 1999; 9:680-689.

29. Mosammaparast N, Pemberton LF. Karyopherins: from nuclear-transport mediators to nuclear-function regulators. Trends Cell Biol. 2004; 14:547-556.

30. Clute P, Pines J. Temporal and spatial control of cyclin B1 destruction in metaphase. Nat Cell Biol. 1999; 1:82-87.

31. Hershko A. Mechanisms and regulation of the degradation of cyclin B. Philos Trans R Soc Lond B Biol Sci. 1999; 354:1571-1575discussion 1575-1576.

32. Moiseeva TN, Bottrill A, Melino G, Barlev NA. DNA damage-induced ubiquitylation of proteasome controls its proteolytic activity. Oncotarget. 2013; 4:1338-1348.

33. Wu-Zhang AX, Newton AC. Protein kinase C pharmacology: refining the toolbox. Biochemical J. 2013; 452:195-209.

34. Tanaka M, Sagawa S, Hoshi J, Shimoma F, Matsuda I, Sakoda K, Sasase T, Shindo M, Inaba T. Synthesis of anilino-monoindolylmaleimides as potent and selective PKCbeta inhibitors. Bioorg Med Chem Lett. 2004; 14:5171-4.

35. Newton AC. Lipid activation of protein kinases. J Lipid Res. 2009; 50:S266-271.

36. Murray NR, Baumgardner GP, Burns DJ, Fields AP. Protein kinase $\mathrm{C}$ isotypes in human erythroleukemia (K562) cell proliferation and differentiation. Evidence that beta II protein kinase $\mathrm{C}$ is required for proliferation. J Biol Chem. 1993; 268:15847-15853. 
37. Hansra G, Garcia-Paramio P, Prevostel C, Whelan RD, Bornancin F, Parker PJ. Multisite dephosphorylation and desensitization of conventional protein kinase $\mathrm{C}$ isotypes. Biochem J. 1999; 342:337-344.

38. Janss AJ, Maity A, Tang CB, Muschel RJ, McKenna WG, Sutton L, Phillips PC. Decreased cyclin B1 expression contributes to G2 delay in human brain tumor cells after treatment with camptothecin. Neuro Oncol. 2001; 3:11-21.

39. Speroni J, Gottifredi V. p21 Regulates the cell cycle...or the other way around? Cell Cycle. 2011; 10:3430.

40. Gillis LD, Leidal AM, Hill R, Lee PW. p21Cip1/WAF1 mediates cyclin $\mathrm{B} 1$ degradation in response to DNA damage. Cell Cycle. 2009; 8:253-256.

41. Schmalz D, Kalkbrenner F, Hucho F, Buchner K. Transport of protein kinase $\mathrm{C}$ a into the nucleus requires intact cytoskeleton while the transport of a protein containing a canonical nuclear localization signal does not. Journal of Cell Science. 1996; 109:2401-2406.

42. Osborn MT, Berry A, Ruberu MS, Ning B, Bell LM, Chambers TC. Phorbol ester induced MDR1 expression in K562 cells occurs independently of mitogen-activated protein kinase signaling pathways. Oncogene. 1999; 18:5756-5764.
43. Rhee SG. Regulation of phosphoinositide-specific phospholipase C. Annu Rev Biochem. 2001; 70:281-312.

44. Raimondi C, Falasca M. Phosphoinositides signalling in cancer: Focus on PI3K and PLC. Adv Biol Reg. 2012; 52:166-182.

45. Yang YR, Follo MY, Cocco L, Suh PG. The physiological roles of primary phospholipase C. Adv Biol Reg. 2013; 53:232-241.

46. Martelli AM, Gilmour RS, Bertagnolo V, Neri LM, Manzoli L, Cocco L. Nuclear localization and signalling activity of phosphoinositidase C beta in Swiss 3T3 cells. Nature. 1992; 358:242-245.

47. Eder AM, Sui X, Rosen DG, Nolden LK, Cheng KW, Lahad JP, Kango-Singh M, Lu KH, Warneke CL, Atkinson EN, Bedrosian I, Keyomarsi K, Kuo WL, Gray JW, Yin JC, Liu J, Halder G, Mills GB. Atypical PKCiota contributes to poor prognosis through loss of apical-basal polarity and Cyclin E overexpression in ovarian cancer. Proc Natl Acad Sci USA. 2005; 102:12519-12524.

48. Soh JW, Weinstein IB. Roles of specific isoforms of protein kinase $\mathrm{C}$ in the transcriptional control of cyclin D1 and related genes. J Biol Chem. 2003; 278:34709-34716. 